\title{
PHENOLOGICAL CHARACTERIZATION OF PEAR TREES (Pyrus communis L.) 'PRINCESINHA' UNDER SEMIARID CONDITIONS IN THE NORTHEASTERN BRAZIL ${ }^{1}$
}

\author{
INEZ VILAR DE MORAIS OLIVEIRA², PAULO ROBERTO COELHO LOPES ${ }^{3}$, \\ RAISSA RACHEL SALUSTRIANO DA SILVA-MATOS ${ }^{4}$
}

\begin{abstract}
The study of phenology is fundamental in introducing cultivars into new regions, mainly in different conditions from those in which they are adapted. The study was conducted in order to characterize the phenological phases of pear (Pyrus communis L.) cultivar 'Princesinha', determine the fixation of fruit rate and quantify the production, as well as to determine the interference of climatic factors on the duration the budding cycle, in the region of São Francisco Valley, Petrolina, PE. To perform the phenological reviews four branches were marked in five plants and the data were expressed as percentage; the variables related to productivity were recorded in all orchard plants, data were submitted to descriptive analysis; climate data and phenological stages were submitted to simple correlation analysis. Under the climatic conditions of the São Francisco Valley the pear 'Princesinha' complete its phenological cycle in 167 days. The plants showed a $16.05 \%$ fruit set with productivity of 35.34 t.ha-1.
\end{abstract}

Index terms: chilling requirement growing season; phenology; semiarid.

\section{CARACTERIZAÇÃO FENOLÓGIA DA PEREIRA (Pyrus communis L.) 'PRINCESINHA' CULTIVADA NO VALE DO SÃO FRANCISCO}

RESUMO - O estudo da fenologia é fundamental na introdução de cultivares em novas regiões, principalmente em condições diferentes daquelas nas quais estão adaptadas. O estudo foi realizado com o objetivo de caracterizar as fases fenológicas da cultivar de pereira (Pyrus communis L.) 'Princesinha', determinar o índice de pegamento de frutos e quantificar a produção, bem como para determinar a interferência de fatores climáticos sobre a duração do ciclo de brotação, na região do Submédio São Francisco, Petrolina-PE. Para realizar as avaliações fenológicas, foram marcados quatro ramos em cinco plantas, e os dados foram expressos em percentual; as variáveis relativas à produtividade foram registradas em todas as plantas do pomar (128 plantas), os dados foram submetidos à análise descritiva; os dados climáticos e de fases fenológicas foram submetidos a análises de correlação simples. Sob as condições climáticas do Vale do Submédio São Francisco, a pereira 'Princesinha' completa seu ciclo fenológico em 167 dias. As plantas apresentaram vingamento de $16,05 \%$, com produtividade de 35,34 t.ha ${ }^{-1}$.

Termos para indexação: fenologia; frutíferas de clima temperado; semiárido.

1(Paper 275-15). Received December 08, 2015. Accepted July 19, 2016.

${ }^{2} E^{2} g^{\mathrm{a}}$. Agr. ${ }^{\mathrm{a}}$, Dra ${ }^{\mathrm{a}}$, VSF Biotecnologia e Diagnose vegetal. E-mail: inezvilar@yahoo.com

${ }^{3}$ Eng. Agr., Dr., Pesquisador Empresa Brasileira de Pesquisa agropecuária, Embrapa Semiárido, Rodovia BR-428, Km 152, s/n - Zona Rural, CEP 56302-970, Petrolina-PE. E-mail: paulo.roberto@embrapa.br

${ }^{4}$ Bióloga, Dra ${ }^{\text {a }}$ Professora do Centro de Ciências Agrárias e Ambientais da Universidade Federal do Maranhão, Campus IV, MA-230, KM 04, s/nº, Boa Vista, CEP 65500-000, Chapadinha-MA - E-mail: raissa.matos@ufma.br 
The pear tree (Pyrus communis L.) belongs to the botanical family Rosaceae which comprises more than twenty species, all from Europe and Asia. According to the Food and Agriculture Organization of the United Nations, in 2013, the main producing countries of this fruit were China $(17,300.751 \mathrm{t})$, the United States $(795,557 \mathrm{t})$ and Italy $(743,029 \mathrm{t})$, with Brazil ranking $46^{\text {th }}$ place in the world with an annual production of only 22,078 t. This production does not meet Brazilian domestic consumption, making the pear the most imported fresh fruit in the country (FAO, 2015). According to Pasa et al. (2011) these data allow us to perceive that pear orchard represents a promising opportunity for Brazilian producers.

The low production of pears in Brazil is attributed to several factors, such as the lack of cultivars well adapted to the climatic conditions, the lack of cold winter weather (FAORO; ORTH, 2010), which do not undergo an adequate number of hours of cold at temperature equal or below $7.2^{\circ} \mathrm{C}$ do not reach an ideal vegetative and productive development. The production of pears ends up being concentrated in five states: Rio Grande do Sul $(10,926$ t), Santa Catarina $(5,427$ t), Paraná $(1,899$ t), Minas Gerais (491 t) and São Paulo (346 t) where harvests occur from February to April (IBGE, 2016; FAORO; ORTH, 2010).

The study of phenological behavior represents a primordial tool to verify the adaptation of cultures inserted in areas that present climatic conditions different from those required by the same (OLIVEIRA et al., 2013a), seeking also to direct the harvests to different time from traditionally producing regions, providing fruit when there is greater lack in the market (LOPES et al., 2012; OLIVEIRA et al., 2013b; OLIVEIRA et al., 2015).

Studies on phenology and production in the São Francisco Valley have shown that it is possible to complete the phenological cycle and produce pears of cultivars 'Housui', 'Kousui' (LOPES et al., 2013a) and 'Triunfo' (OLIVEIRA et al., 2015) on tropical semi-arid conditions. The cultivar 'Princesinha' comes from the genetic improvement program of IAC, and resulting from the crossing between cultivars 'Hood' $x$ 'Packham's Triumph' which has high adaptation to the mild winter regions and presents early production (CHAGAS et al., 2008).

The study of phenological and productive behavior of cv. 'Pricesinha' under tropical semi-arid conditions can confirm the hypothesis that this is more premature than the cultivars 'Housui', 'Kousui' and 'Triunfo' evaluated under the same climatic conditions. And also contribute to the diversification of crops in irrigated areas of the Brazilian Northeast, being an important strategy that will allow the production and supply of fruits at different time than the traditionally producing regions. The aim of this study was to prove the hypothesis that $\mathrm{cv}$. "Princesinha" is the most viable cultivars in the semiarid. The study was carried out with the objective of characterizing the phenological phases of a pear orchard (Pyrus communis L.) cultivar 'Princesinha'; to determine the index of fruit germination and to quantify the production as well as to determine the interference of climatic factors on the duration of the sprouting cycle in São Francisco Valley region, Petrolina, PE.

The study was conducted from August 2013 to January 2014 in an experimental orchard located in the Experimental Station of Bebedouro, belonging to the Brazilian Agricultural Research Corporation (Embrapa Semiarid), in Petrolina-PE $\left(9^{\circ} 09 \mathrm{~S}\right.$ and $40^{\circ} 22^{\prime} \mathrm{W}$ and at an altitude of $365.5 \mathrm{~m}$ above sea level). According to Köeppen (1948) the region climate is classified as Bswh, corresponding to a semiarid region with average annual temperature of $26.0^{\circ} \mathrm{C}$ and minimum and maximum of $21.2^{\circ} \mathrm{C}$ and $32.7^{\circ} \mathrm{C}$ respectively. The average annual rainfall is $481.7 \mathrm{~mm}$, with the highest rainfall observed from February to April. The dry season occurs from June to November and the air average relative humidity is $67 \%$. During the experiment execution the climatic data (Figure 1) were collected from the Experimental Station mentioned above.

The pear orchard (Pyrus communis L.) used in this study was planted with seedlings of the naked root type of cv. 'Princesinha' (Pyrus communis L.), grafted on rootstocks 'Pirus' (Pyrus calleryana L.). The seedlings were planted in January 2008 and conducted in a "central leader" system, according to Centellas-Quezada et al. (2003). The orchard is distributed in a row with planting spacing of $5.0 \mathrm{~m}$ between rows and $2.0 \mathrm{~m}$ between plants, and the used irrigation system was double line drip irrigation with ten emitters (flow of $2 \mathrm{~L} \mathrm{~h}^{-1}$ ) per plant. The study area soil is classified as Dystrophic Red-Yellow Argisol, medium / clayey texture, flat relief (GIONGO et al., 2011).

The orchard fertilization was carried out according to recommendations by CentellasQuezada et al. (2003). In the first year the arching of branches was carried out; in the second year, prior to defoliation, the pruning and bending of the branches were done to stimulate the buds development. The peeling of pear trees was carried out on August 18,2013 , followed by pruning to eliminate excess branches. The breakdown of dormancy was done with the application of hydrogen cyanamide $\left(\right.$ Dormex $\left.^{\circledR}\right)$ 
$1.0 \%$ associated with the mineral oil $\left(\right.$ Assist $\left.^{\circledR}\right) 2.0 \%$, applied with costal spray, with conical nozzle until the point of drainage. The application was performed when the plants were in the stadium of dormant buds, recommended by Centellas-Quezada et al. (2003).

The phenological behavior of the pear tree variety 'Princesinha' was evaluated through visual observations made daily from the pruning and application of Dormex ${ }^{\circledR}$ until the harvest as recommended by Lopes et al. (2013b). For phenological analysis, 5 plants were randomly selected in which 4 branches were selected, each one being distributed, totaling 20 branches. The determinations of the phenological phases were based on the dormant buds scale according to Alexandre et al. (2001): A: dormant buds; B: green tip; C: green shoot; D: white shoot; E: beginning of flowering; F: full bloom; G: end of flowering; H: fruiting; I: fruit growth; and J: ripe fruit. The duration of each phenological phase was recorded in number of days.

All 128 orchard plants were used for the quantification of the production, which was based on the methodology by Lopes et al. (2013b) that evaluated the following production variables: I) plant germination (\%): relationship between number of flowers (of all corymb present in the selected branches) and number of fruits (\%); ii) number of fruits per plant; iii) fruit production per plant $(\mathrm{kg})$ measured using a precision scale $\left(\right.$ Filizola $^{\circledR}$ brand, model CF15, with $0.5 \mathrm{~g}$ precision); and iv) productivity obtained by multiplying the production of fruits per plant and total number of plants in one hectare.

The phenological phases were evaluated in 5 plots (each composed of 4 branches) and were expressed as a percentage; the production data were submitted to descriptive analysis. While the climatic and phenological phases data were submitted to the simple correlation analyzes performed with the Program Assistat ${ }^{\mathbb{}}$.

The results obtained show that pear tree cv. 'Princesinha' completed its phenological cycle (Figure 2), in tropical semiarid condition, reaching the harvest point at 167 days in 2014 (Table 1) it shows later harvest point than the 'Kousui', 'Housui' and 'Triunfo' varieties which completed their cycles in 115, 128 and 144 days respectively (LOPES et al., 2013a; OLIVEIRA et al., 2015). The accumulation of cold hours below $7.2^{\circ} \mathrm{C}$ during the cold season allows the temperate fruit to overcome its dormancy (LEGAVE et al., 2008; TROMP, 2005).

The pear tree submitted to the tropical semiarid condition, even though not occurring cold hours below $7.2^{\circ} \mathrm{C}$, the pear varieties 'Kousui', 'Housui'
(LOPES et al., 2013a) and 'Triunfo'(OLIVEIRA et al., 2015) and apple tree 'Eva' (LOPES et al., 2012), 'Condessa' (OLIVEIRA et al. (2013b), 'Daiane' (OLIVEIRA et al., 2013b) and 'Princesa' (LOPES et al., 2013b) overcame all phenological phases from the induction of defoliation and the breakdown of artificial dormancy as well as in the present study with the pear tree 'Princesinha'. According to Oliveira et al. (2013b) this can be attributed to the crop treatments used such as pruning, defoliation and breakage of dormancy which stimulated the buds.

It took 32 days for the buds to pass from dormancy stage (A) to full bloom (F) (Table 1, Figure 1), Higher than the cultivars 'Housui', 'Kousui' and 'Triunfo', which required respectively 13, 18 and 23 days to reach full bloom, grown under the same climatic conditions, in the city of Petrolina-PE (LOPES et al., 2013a; OLIVEIRA et al., 2015).This great difference between sprouting and flowering should be carefully considered since it can lead to losses to fruiting, probably due to competition for nutrients between vegetative growth and flowering buds (LOPES et al., 2013a).

The phenological phase of longer duration corresponded from fruit growth stage (I) to fruit maturation, for which it took 109 days reaching a fruiting index of $17.02 \%$ (Table 1). Longer time than cultivars 'Housui' (41 days) and 'Kousui' (34 days), but they had a lower fruiting index of 6.0 and 1.0, respectively (LOPES et al., 2013a). This difference in the period of phenological phases may be associated with that reported by Petri et al. (2008), who stated that in regions with low accumulation of cold there are variations of the flowering period, indicating that the variation on number of days for flowering and the end of the cycle are related to the temperature.

Pear tree cv 'Princesinha' obtained an average yield per plant of $35.34 \mathrm{~kg}$ and a productivity of 35.34 $\mathrm{t} \mathrm{ha}^{-1}$ (Table 2) higher than the yield of 'Triunfo' cultivar which was $26.33 \mathrm{t} \mathrm{ha}^{-1}$ (OLIVEIRA et al., 2015) and that national average was $12.96 \mathrm{t} \mathrm{ha}^{-1}$ in 2014 (IBGE, 2016).

The phenological phases had no significant correlation with the temperature, relative humidity and radiation of the period. There was a strong positive correlation only with the precipitation variable (Table 3 ). These results differ from those obtained by Oliveira et al. (2015) for the 'Triunfo' pear tree in which the cultivar presented a high and significant correlation for all variables except precipitation. The correlation obtained in the present study was similar to those reported by Lopes et al. (2013a) for 'Housui' and 'Kousui' pear tree, which 
correlated significantly with precipitation and radiation.

The results indicate that: i) it is possible to produce pear fruits cv. 'Princesinha' in tropical semiarid condition; ii) the phenological cycle of pear tree cv. 'Princesinha' in tropical semiarid condition was 167 days, longer than other pear tree cultivars in the same region; iii) pear tree 'Princesinha' presents germination of $16.05 \%$, with 251 fruits per plant, production of $35.34 \mathrm{~kg}$ and yield of $35.34 \mathrm{t} \mathrm{ha}^{-1}$.

TABLE 1 - Phenological phases of pear tree (Pyrus communis L.) 'Princesinha' in Petrolina-PE, 2013/2014.

\begin{tabular}{ccc}
\hline Phenological Phases & Days & Buds (\%) \\
\hline A & 0 & 100.00 \\
B & 19 & 25.53 \\
C & 21 & 21.28 \\
D & 24 & 21.28 \\
E & 28 & 21.28 \\
F & 32 & 21.28 \\
G & 37 & 21.28 \\
H & 47 & 17.02 \\
I & 58 & 17.02 \\
J & 167 & 17.02 \\
\hline
\end{tabular}

A: dormant buds; B: green tip; C: green shoot; D: white shoot; E: beginning of flowering; F: full bloom; G: end of flowering; H: fruiting; I: fruit growth; J: ripe fruit.

TABLE 2 - Germination, number of fruits per plant (NFP), fruit production per plant (PP) and production of pear tree (Pyrus communis L.) 'Princesinha' in Petrolina-PE, 2013/2014.

\begin{tabular}{lcccc}
\hline & GERMINATION (\%) & NFP & $\begin{array}{c}\text { PP } \\
(\mathrm{kg})\end{array}$ & Productivity (t.ha $\left.{ }^{-1}\right)$ \\
\hline Average & 16.05 & 251.00 & 35.34 & 35.34 \\
Amplitude & 1.80 & 138.00 & 11.3 & 11.3 \\
Coefficient of variation (\%) & 4.24 & 21.44 & 13.21 & 13.21 \\
Variance & 0.46 & 2896.00 & 21.81 & 21.81 \\
Standard deviation (\%) & 0.68 & 53.81 & 4.67 & 4.67 \\
\hline
\end{tabular}

TABLE 3 - Simple correlation coefficients (r) between climatic factors and phenological phases of pear tree (Pyrus communis L.) 'Princesinha' in Petrolina-PE in the year 2013/2014.

\begin{tabular}{cccccc}
\hline & Phenological Phases $^{1}$ & Temperature $^{2}$ & RH $^{3}$ & Radiation $^{4}$ & Precipitation $^{5}$ \\
\hline Phenological Phases $^{1}$ & - & $-0.0495^{\mathrm{ns}}$ & $0.1133^{\mathrm{ns}}$ & $0.0567^{\mathrm{ns}}$ & $0.9651^{* *}$ \\
Temperature $^{2}$ & - & - & $-0.9870^{* *}$ & $0.8475^{* *}$ & $-0.1611^{\mathrm{ns}}$ \\
$\mathrm{RH}^{3}$ & - & - & - & $-0.8430^{* *}$ & $0.2322^{\mathrm{ns}}$ \\
Radiation $^{4}$ & - & - & - & - & $-0.0954^{\mathrm{ns}}$ \\
Precipitation & - & - & - & - & - \\
\hline
\end{tabular}

1: Duration of the phenological phases; 2: Average temperature; 3: Relative Humidity; 4: Average global radiation; 5: Precipitation in $\mathrm{mm} ; * *$ : Significant at $1 \%$ probability; $*$ : Significant at $5 \%$ probability; ${ }^{\text {ns: }}$ not significant. 
$\theta$

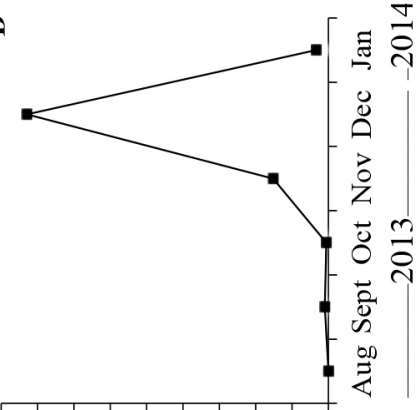

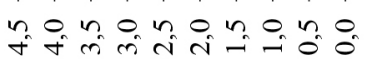

(uшi) II घyuाey

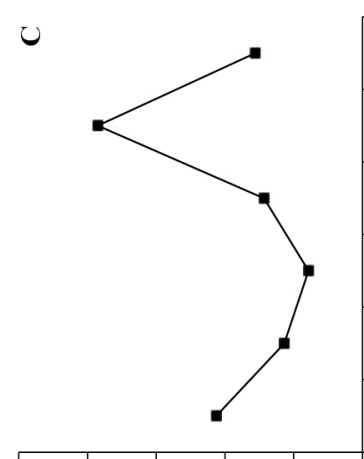

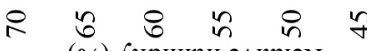

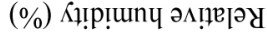

$\leadsto$

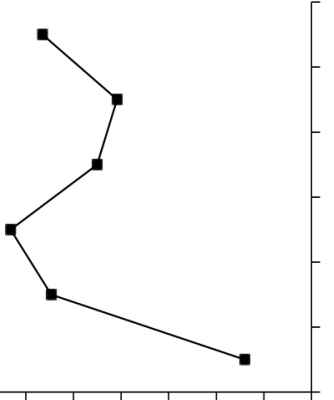

तथ ${ }_{1}-\mathrm{e} ! \mathrm{p}_{\tau}-\mathrm{UL}$

[u) ио!̣!

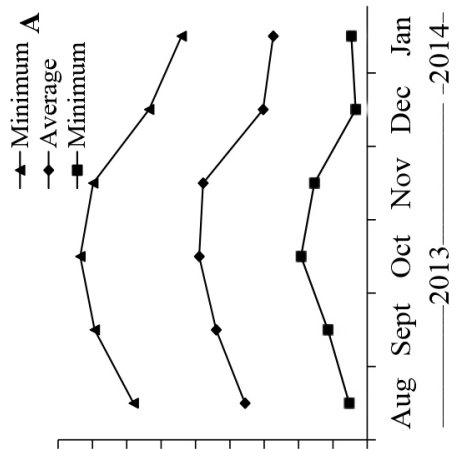

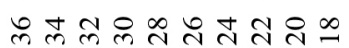

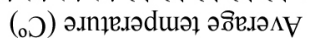
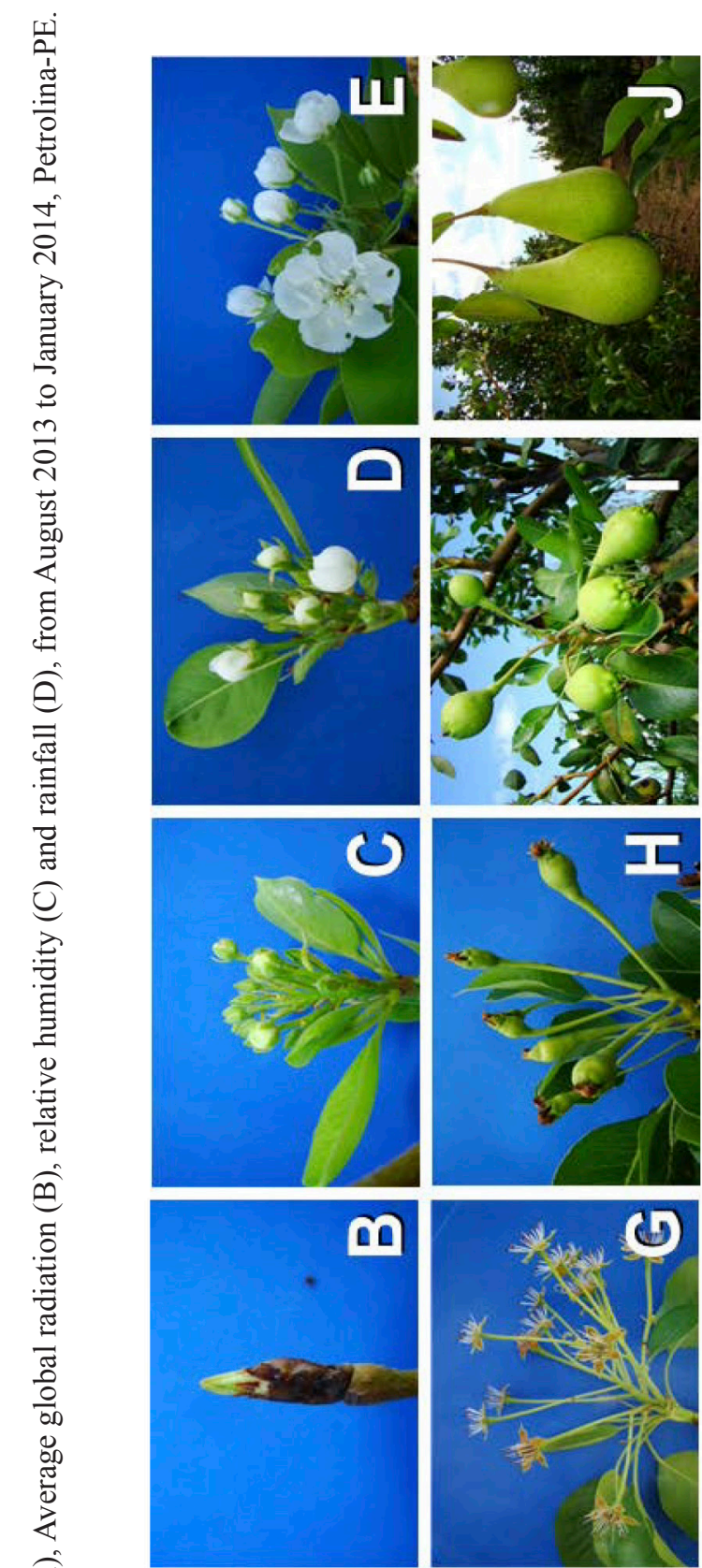

อำ
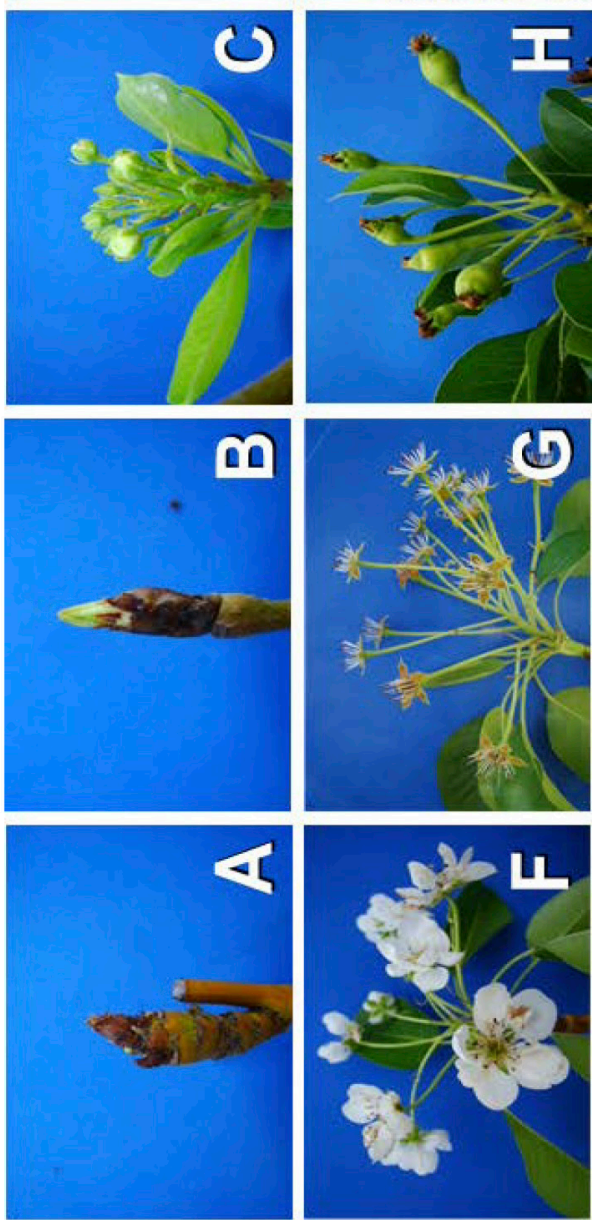

$\ddot{\theta}$

苍

गี

$\ddot{ن}$

$\ddot{0}$

ญี

$\ddot{\varphi}$

荐.

כ

芩

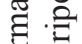

훙

$\ddot{\sim} \ddot{E}$

+๐

定

ㄹ.

m

음

ㄸำ

$\Xi$

입

唡

.$\Xi$

()

ปี

त

0

I $\bar{g}$

둥

วิن

$\dot{-1}$

ฐ

총응

突

芒

定

?

幽

$\div$

芉艺

냉.

\&

ब.

용

तु

0.0

bi

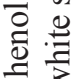

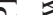

'

동 


\section{REFERENCES}

ALEXANDRE, J.; SOARES J.; SILVA, A. A pêra Rocha. In: SOARES, J. (Coord.). O livro da pereira rocha. Cadaval: Associação Nacional de Produtores de Pera Rocha, 2001. v.1, cap 1, p.27- 42.

CENTELLAS-QUEZADA, A.; NAKASU, B. H.; HERTE, F. G. (Ed.). Pêra: produção. Brasília, DF: Embrapa Informação Tecnológica, 2003. 105p. (Frutas do Brasil, 46).

CHAGAS, E. A.; CAMPO DALL'ORTO, F. A.; OJIMA, M.; BARBOSA, W.; PIO, R. Pear IAC Princesinha: New European type cultivar for subtropical climate. Acta Horticulturae, The Hague, v.800, n.1, p.507-510, 2008

FAO - Food and Agriculture Organization of the United Nations. FAOSTAT: statistics database. Disponível em: $<$ http://apps.fao.org/>. Acesso em: 9 nov. 2015.

FAORO, I. D.; ORTH, A. I. Qualidade de frutos da pereira-japonesa colhidos em duas regiões de Santa Catarina, Brasil. Revista Brasileira de Fruticultura, Jaboticabal, v.32, n.1, p.308-315, 2010.

GIONGO, V.; GALVÃO, S. R. da S.; MENDES, A. M. S.; GAVA, C. A. T.; CUNHA, T. J. F. Soil organic carbon in the Brazilian Semi-arid Tropics. Dynamic Soil, Dynamic Plant, Tokyo, v.5, n.1, p.12-20, 2011.

IBGE - Instituto Brasileiro de Geografia e Estatística. Sidra: produção agrícola municipal. Disponível em: <http://www.sidra.ibge.gov.br/>. Acesso em: 28 maio 2016.

KÖEPPEN, W. Climatologia. Buenos Aires: Panamericana, 1948. 478 p.

LEGAVE, J. M.; FARRERA, I.; ALMERAS, T.; CALLEJA, M. Selecting models of apple flowering time and understanding how global warming has had an impact on this trait. Journal of Horticultural Science and Biotechnology, Ashford, v.83, n.1, p.76-84, 2008.

LOPES, P. R. C; OLIVEIRA, I. V. M.; SILVAMATOS, R. R. S.; CAVALCANTE, Í. H. L. Caracterização fenológica, frutificação efetiva e produção de maçãs 'Eva' em clima semiárido no nordeste brasileiro. Revista Brasileira de Fruticultura, Jaboticabal, v.34, n.4, p.1277-1283, 2012.
LOPES, P.R.C.; OLIVEIRA, I.V.M.; SILVA, R.R.S.; CAVALCANTE, Í.H.L. Growing Princesa apples under semiarid conditions in northeastern Brazil Acta Scientiarum. Agronomy, Maringá, v.35, p.93-99, 2013b.

LOPES, P.R.C.; OLIVEIRA, I.V.M.; SILVAMATOS, R.R.S. Caracterização fenológica de pereiras 'Housui' e 'Kousui' cultivadas sob clima semiárido no nordeste do Brasil. Revista Brasileira de Fruticultura, Jaboticabal, v.35, n2, p.670-675, 2013a.

OLIVEIRA, I. V. M.; LOPES, P. R. C.; SILVAMATOS, R. R. S. Caracterização Fenológica e Frutificação Efetiva de Macieira 'Daiane' sob Condições Semiáridas do Nordeste do Brasil. Revista de Ciências Agro-Ambientais, Cáceres, v.11, p.153-158, 2013b.

OLIVEIRA, I. V. M.; LOPES. P. R. C.; SILVAMATOS, R. R. S. Avaliação fenológica da pereira 'Triunfo' cultivada em clima semiárido no Nordeste do brasil na safra de 2012. Revista Brasileira de Fruticultura, Jaboticabal, v.37, n.1, p.261-266, 2015.

OLIVEIRA, I.V.M.; LOPES, P.R.C.; SILVA, R.R.S.; CAVALCANTE, Í.H.L. Fenologia da macieira cv. 'Condessa' no Vale do São Francisco. Revista de Ciências Agrárias, Lisboa, v.36, p.23-30, 2013a.

PASA, M. da S.; FACHINELLO, J. C.; SCHMITZ, J.D.; SOUZA, A.L.K. de; HERTER, F.G. Hábito de frutificação e produção de pereiras sobre diferentes porta-enxertos. Pesquisa Agropecuária Brasileira, Brasília, DF, v.46, n.9, p.998-1005, 2011.

PETRI, J.L.; HAWERROTH, F.J.; LEITE, G.B Fenologia de espécies silvestres de macieira como polinizadora das cultivares Gala e Fuji. Revista Brasileira de Fruticultura, Jaboticabal, v.30, n.4, p.868-874, 2008.

TROMP, J. Dormancy. In: TROMP, J.; WEBSTER, A.D.; WERTHEIM, S.J. (Ed.). Fundamentals of temperate zone tree fruit production. Leiden: Backhuys Publishers BV, 2005. p.65-73. 